Whitaker HA, eds. Studies in neurolinguistics. New York: Academic Press, 1976:293-306.

34. Freedman M, Alexander MP, Naeser MA. Anatomic basis of transcortical motor aphasia. Neurology 1984;34:409-417.

35. Buge A, Escourolle R, Rancurel G, Poisson M. Mutisme akinétique et ramollissement bicingulaire. Trois observations anatomo-cliniques. Rev Neurol 1975;131:121-137.

36. Kertesz A, Sheppard A, MacKenzie R. Localization in transcortical sensory aphasia. Arch Neurol 1982;39:475-478.

37. Caplan D, Hildebrandt N, Makris N. Location of lesions in stroke patients with deficits in syntactic processing in sentence comprehension. Brain 1996;119:933-949.

38. Naeser MA, Helm-Eastabrooks N, Haas G, Auerbach S, Srinivasan M. Relationship between lesion extent in 'Wernicke's area' on computed tomographic scan and predicting recovery of comprehension in Wernicke's aphasia. Arch Neurol 1987; $44: 73-82$

39. Démonet JF, Cardebat D, Angibaud G, et al. Brain and language: correlative study between MRI and linguistic symptoms in aphasic patients. Second meeting of the PanEuropean Neurological Society of Neurology; December 7-11, 1991; Wien, Austria.

40. Godefroy O, Rousseaux M, Leys D, Destée A, Scheltens P, Pruvo JP. Frontal lobe dysfunction in unilateral lenticulostriate infarcts. Prominent role of cortical lesions. Arch Neurol 1992;49:1285-1289.

41. Brown P, Marsden CD. What do the basal ganglia do? Lancet 1998;351:1801-1804.

\title{
Neuro/mages
}

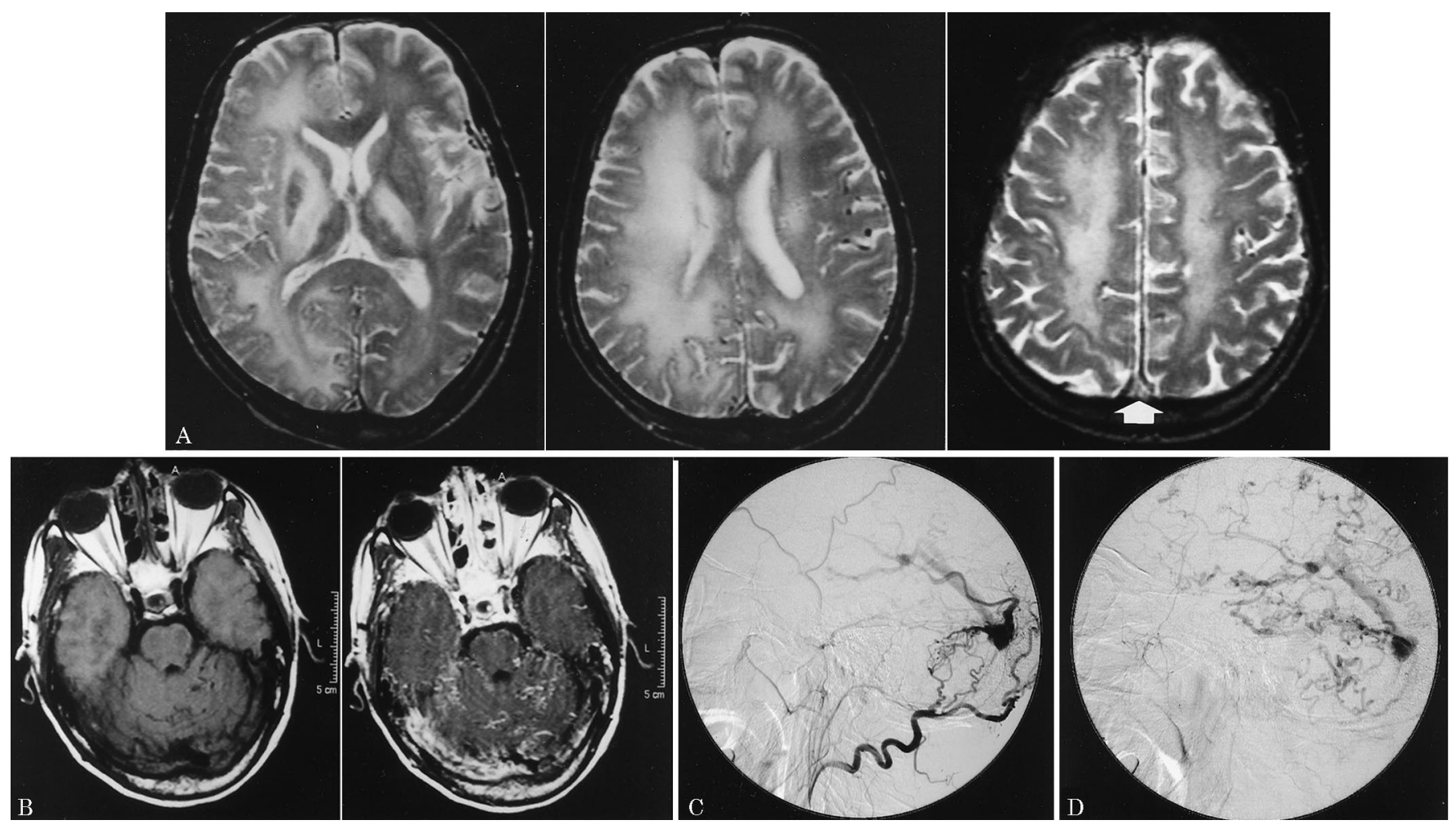

Figure. (A) T2-weighted imaging. (B) T1-weighted and gadolinium-enhanced T1-weighted imaging. (C) Arterial phase of the right external carotid arteriogram. (D) Venous phase of the arteriogram.

\section{Dural arteriovenous fistula mimicking leukoencephalopathy}

K. Ikeda, MD, PhD, Y. Iwasaki, MD, M. Osako, MD

Y. Ichikawa, MD, M. Kinoshita, MD, Tokyo, Japan

A 49-year-old man had headache and fever for 1 month. Neurologic examination showed cognitive dysfunction: recent memory loss, dyscalculia, and disorientation. Muscle stretch reflexes were increased with Babinski signs. Sensory and cerebellar function were normal without meningeal signs. T2-weighted MRI revealed hyperintense signal areas in the internal capsules, globus pallidus, and subcortical white matter regions (A). Normal flow void appearance was not seen in the superior sagittal sinus (A, arrow). Diffusion-weighted imaging also disclosed diffuse hyperintensity in the subcortical white matter. In addition, T1- weighted MRI showed abnormal flow void sign in the cerebellum with gadolinium enhancement (B). Brain MR angiography suggested arteriovenous shunts. Arterial phase of the right external carotid arteriogram indicated dural arteriovenous fistula in the straight and transverse sinus (C). The venous phase of arteriogram demonstrated prominent venous collaterals and congestion in the great vein of Galen, inferior sagittal, and straight sinus (D). The internal carotid angiogram did not define the superior sagittal, transverse, and sigmoid sinus obviously. These images strongly support that perturbation of the venous outflow and sinus thrombosis could induce diffuse brain edema or infarction. Dural arteriovenous fistula occasionally causes a unique distribution of MRI lesions mimicking acute leukoencephalopathy. 


\section{Neurology}

\section{Dural arteriovenous fistula mimicking leukoencephalopathy Neurology 2000;54;1123 \\ DOI 10.1212/WNL.54.5.1123}

This information is current as of March 14, 2000

\section{Updated Information \&}

Services

Permissions \& Licensing

Reprints including high resolution figures, can be found at: http://n.neurology.org/content/54/5/1123.full

Information about reproducing this article in parts (figures,tables) or in its entirety can be found online at:

http://www.neurology.org/about/about_the_journal\#permissions

Information about ordering reprints can be found online:

http://n.neurology.org/subscribers/advertise

Neurology ${ }^{\circledR}$ is the official journal of the American Academy of Neurology. Published continuously since 1951, it is now a weekly with 48 issues per year. Copyright. All rights reserved. Print ISSN: 0028-3878. Online ISSN: 1526-632X.

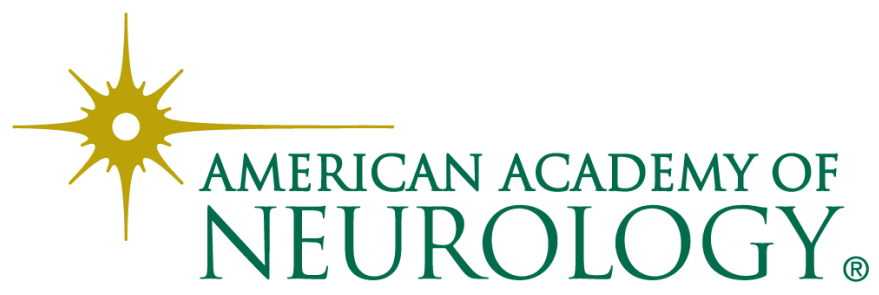

